\title{
PEMBERDAYAAN MASYARAKAT DALAM RANGKA KETERWUJUDAN INTERAKSI SOSIAL DAN KESEJAHTERAAN DI DESA CIBEBER I
}

\author{
Arief Goeritno $^{1}$, Frieda Nuraeni, Jiqie Jihad Haqieqi ${ }^{2}$ \\ arief.goeritno@ft.uika-bogor.ac.id \\ Dosen Fakultas Teknik ${ }^{1}$, Mahasiswa KKN Kelompok 61 Tahun $2018^{2}$
}

\begin{abstract}
ABSTRAK
Kuliah Kerja Nyata Tematik Terintegritas (KKN-TT) Kelompok 52 merupakan salah satu program pengabdian mahasiswa pada masyarakat yang diselenggarakan oleh Universitas Ibn Khadun Bogor. Kegiatan KKN-TT yang dilaksanakan dikhususkan untuk masyarakat di Desa Cibeber I, Kecamatan Leuwiliang, Kabupaten Bogor dengan program "Pemberdayaan Masyarakat Dalam Rangka Keterwujudan Interaksi Sosial dan Kesejahteraan di Desa Cibeber I Kecamatan Leuwiliang Kabupaten Bogor”. Program ini diharapkan mampu berkonstribusi terhadap masyarakat berupa penyaluran dan peningkatan minat pendidikan dan keterciptaan Desa Cibeber I yang berdikari, hijau, dan asri. Perencanaan dan pelaksanaan program kerja KKN Tematik Terintegrasi ini merupakan langkah awal dalam pelaksanaan kegiatan dalam bentuk pengabdian pada masyarakat selama lebih-kurang sebulan terhitung mulai tanggal 07 Agustus 2018 sampai 06 September 2018. Beberapa program yang dilaksanakan, meliputi Pengajaran di Sekolah, Bimbingan Belajar, Penyuluhan Menabung Sejak Dini, Jalan Sehat, Penyuluhan Kesehatan, Penanaman Pohon, Kerja Bakti, Pos Kesehatan Desa (Poskesdes), Imunisasi Campak, Update pada Google Maps untuk lokasi Kantor Desa Cibeber I, Taman Pendidikan Al Quran, dan Pengajaran Fiqh Ibadah. Hasil utama yang telah dicapai berupa teratasinya konservasi lahan dan mitigasi bencana di Desa Cibeber I dan kemunculan semangat anak-anak untuk pengenyaman pendidikan sampai dengan perguruan tinggi. Secara umum hasil kegiatan telah sesuai dengan rencana yang telah ditetapkan sebelumnya. Sejumlah hambatan dan halangan ditemui pada beberapa kegiatan KKN-TT kali ini, namun dengan penanganan yang terkoordinasi dengan pihak terkait, sehingga diperoleh solusi sesuai harapan dan sedapat mungkin jadwal kegiatan tidak terganggu, sehingga program tetap berjalan dengan optimal dan terkoordinasi.
\end{abstract}

Kata Kunci : Cibeber 1, KKN-TT, Pemberdayaan masyarakat.

\section{PENDAHULUAN}

\section{Analisis Situasi}

Desa Cibeber I merupakan salah satu desa di Kecamatan Leuwiliang, Kabupaten Bogor. Tingkat pendidikan di wilayah ini terbilang masih cukup rendah, sebagian penduduk usia lanjut hanya menempuh pendidikan Sekolah Dasar (SD), sedangkan para pemuda hanya menempuh pendidikan hingga jenjang SMP/SMA. Hal ini karena faktor ekonomi yang masih dalam taraf menengah kebawah, kurangnya kesadaran masyarakat akan pentingnya pendidikan untuk masa depan. 
Meskipun demikian, masyarakat juga sudah mampu memanfaatkan potensi alam yang ada dengan menjadikannya sebagai penyokong perekonomian masyarakat. Ada beberapa macam potensi alam yang ada di Desa Cibeber I diantara adalah, daerah pesawahan dan daerah perkebunan yang cukup luas. Dan terdapat industri rumahan yang memproduksi batu bata merah. Potensi ini menjadi sarana pekerjaan untuk masyarakan Desa Cibeber I. Keadaan aksesibilitasi atau jalan Desa Cibeber I sudah mengalami pengerasan dengan aspal, akan tetapi kondisi jalan saat ini sudah mengalami kerusakan yang menimbulkan kubangan air jika hujan turun..

\section{Bidang Pendidikan}

a) Kurangnya fasilitas pendidikan

Pendidikan merupakan modal yang sangat penting dalam meningkatkan perekonomian, karena Sumber Daya Manusia yang berkualitas tercipta dari pendidikan yang berkualitas pula. Sumber Daya Manusia yang berpendidikan akan memiliki banyak informasi dan kemampuan untuk mengubah segala potensi menjadi peluang. Namun sungguh disayangkan walaupun di desa terdapat sekolah tingkat SD sampai SMA. Akan tetapi, desa yang penuh Sumber Daya yang berlimpah justru kekurangan fasilitas pendidikan. Di Desa Cibeber 1 untuk pendidikan jenjang SMP tidak memiliki fasilitas yang memadai, ruangan kelas harus digunakan bergantian dengan SD, sehingga suasana kelas tidak kondusif, serta tidak adanya perpustakaan dan lapangan. b) Tingkat pendidikan yang rendah

Pendidikan yang rendah mengakibatkan sempitnya kemampuan masyarakat untuk berinovasi, sulit dalam mendapatkan pekerjaan yang layak, menghambat kemajuan teknologi, kesulitan dalam mengelola Sumber Daya Alam, dan menemukan peluang usaha.

c) Kesadaran akan pentingnya pendidikan sangat rendah

Faktor ekonomi menjadi alasan utama untuk melanjutkan pendidikan hingga ke perguruan tinggi. Orangtua pun menanamkan dalam benak anaknya sedari kecil bahwa mereka tidak sanggup untuk menyekolahkan hingga perguruan tinggi.

\section{Bidang Kesehatan dan Lingkungan}

a) Kurangnya kesadaran menjaga lingkungan

Masyarakat masih belum dapat mengelola sampah dengan baik, hal ini karena semua sampah dibuang ke pinggir kali serta pembakaran sampah yang dapat meningkatkan pencemaran dan merusak kesehatan terutama organ pernapasan.

b) Kurangnya kesadaran hidup bersih Selain itu kesadaran akan pentingnya pola hidup sehat juga masih terlihat cukup rendah. Terlihat dari masyarakat yang mencuci pakaian, peralatan dapur, mandi, dan buang hajat di sungai yang dipinggirnya tertumpuk sampah.

c) Susah medapatkan air bersih

Beberapa RW di Desa Cibeber 1 belum masuk saluran PDAM sehingga masyarakat mengandalkan air sumur. Akan tetapi air yang didapat keruh dan terkadang berbau besi. Kesulitan air bersih diperparah dengan iklim kemarau, sehingga mau tidak mau 
masyarakat sekitar memenuhi kebutuhan air sehari-hari dari air sungai.

\section{Bidang Ekonomi}

Kelemahan struktur permodalan dan akses terhadap sumber permodalan. Modal merupakan faktor utama untuk memulai suatu usaha, besar kecilnya usaha yang akan dibangun tergantung dari modal yang dimiliki oleh penguasa tersebut. Di Desa Cibeber I, sumber untuk memperoleh pinjaman modal dikatakan cukup sulit.

\section{Bidang Agama}

a) Anak-anak Desa Cibeber 1 belum memahami dengan benar tata cara wudhu dan sholat sesuai yang diajarkan oleh Nabi Muhammad sallallahu 'alaihi wa sallam.

b) Ketika sakit, masyarakat langsung berobat ke posyandu desa atau mengkonsumsi obat warung. Tidak khawatir sebanyak apa mengkonsumsi obat-obat

\section{Keadaan Geografis}

Desa Cibeber I, Kecamatan Leuwiliang berada di wilayah administrasi Kabupaten Bogor dengan luas wilayah 616.695 Ha. Secara umum, keadaan tofografi Desa Cibeber I merupakan daerah daratan dan sebagian kecil perbukitan dengan ketinggian antara 500-700 meter diatas permukaan laut, dengan suhu rata-rata $32^{\circ} \mathrm{C}$. Desa Cibeber I terbagi atas 5 Dusun, 12 Rukun Warga, dan 36 Rukun Tetangga. Iklim di Desa Cibeber I sebagaimana di Desa-desa lain di wilayah Indonesia mempunyai iklim kemarau dan penghujan. Batas-batas wilayah di Desa Cibeber I, adalah:

$\begin{array}{ll}\text { Sebelah Utara } & : \begin{array}{l}\text { Desa Leuwiliang } \\ \text { dan Desa Karehkel }\end{array} \\ \text { Sebelaha } & : \text { Desa Cibeber II } \\ \text { Selatan } & \text { Desa Leuwiliang } \\ \text { Sebelah Timur } & : \text { dan Desa } \\ & \text { Leuwimekar } \\ \text { Sebelah Barat } & : \text { Desa Leuwisadeng }\end{array}$

Peta lokasi Desa Cibeber I, seperti ditunjukkan pada Gambar 2.1.

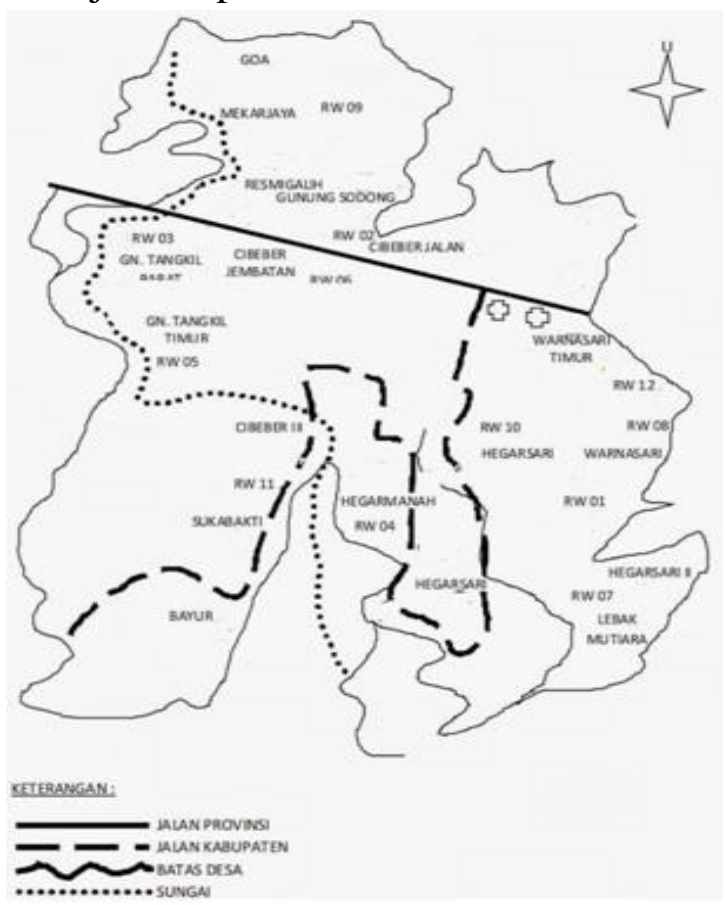

Berdasarkan letak geografis dan luas wilayah Desa, sebenarnya memiliki potensi yang menjanjikan untuk bidang pertanian. Jenis pertanian yang beraneka ragam seperti kacang tanah, cabai, padi dan singkong. Adapun luas persawahan \pm $105,359 \mathrm{Ha}$ dan luas pekarangan $\pm 19 \mathrm{Ha}$

\section{Kondisi Masyarakat}

Secara umum penduduk Desa Cibeber I dikatakan jarang, apabila dibandingkan dengan luas wilayah desa. Berdasarkan data yang diperoleh dari Kantor Desa Cibeber I, jumlah penduduk sebanyak 9.645. Kondisi masyarakat Desa Cibeber I, dijelaskan dengan kondisi 
pendidikan, sosia-ekonomi, sosio-

keagamaan, dan hubungan dalam

masyarakat.

\section{METODE PELAKSANAAN}

\section{Tahapan Pelaksanaan}

Tahapan pelaksanaan untuk kegiatan Kuliah Kerja Nyata Tematik Terintegrasi Kelompok 52, Universitas Ibn Khaldun Bogor dibuat dalam bentuk bagan. Bagan tahapan pelaksanaan kegiatan, seperti ditunjukkan pada Gambar 3.1.
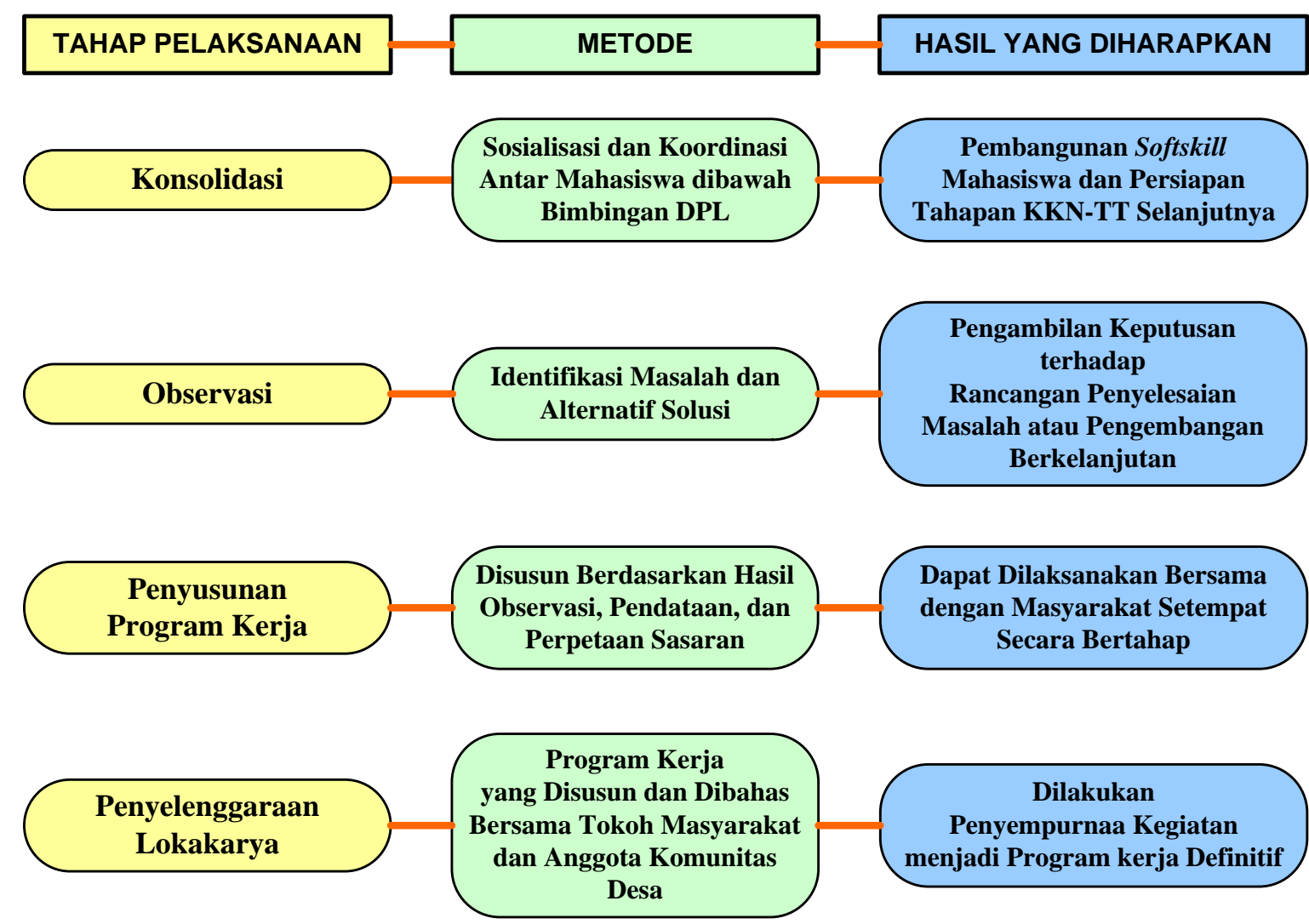

Bagan tahapan pelaksanaan kegiatan

Jadwal kegiatan KKN-TT Kelompok 52

\begin{tabular}{|c|c|c|c|c|c|}
\hline \multirow{2}{*}{ No. } & \multirow{2}{*}{ Program Kegiatan } & \multicolumn{4}{|c|}{ Pekan ke- } \\
\hline & & $\mathbf{1}$ & 2 & 3 & 4 \\
\hline \multicolumn{6}{|c|}{ BIDANG PENDIDIKAN } \\
\hline 1 & Pengajaran di Madrasah Ibtidaiyyah & & & & \\
\hline 2 & Penyelenggaraan Bimbingan Belajar & & & & \\
\hline \multicolumn{6}{|c|}{ BIDANG KESEHATAN DAN LINGKUNGAN } \\
\hline 1 & Membantu Poskesdes & & & & \\
\hline 2 & Pemberian Vitamin A dan Imunisasi & & & & \\
\hline 3 & Jalan Sehat & & & & \\
\hline
\end{tabular}




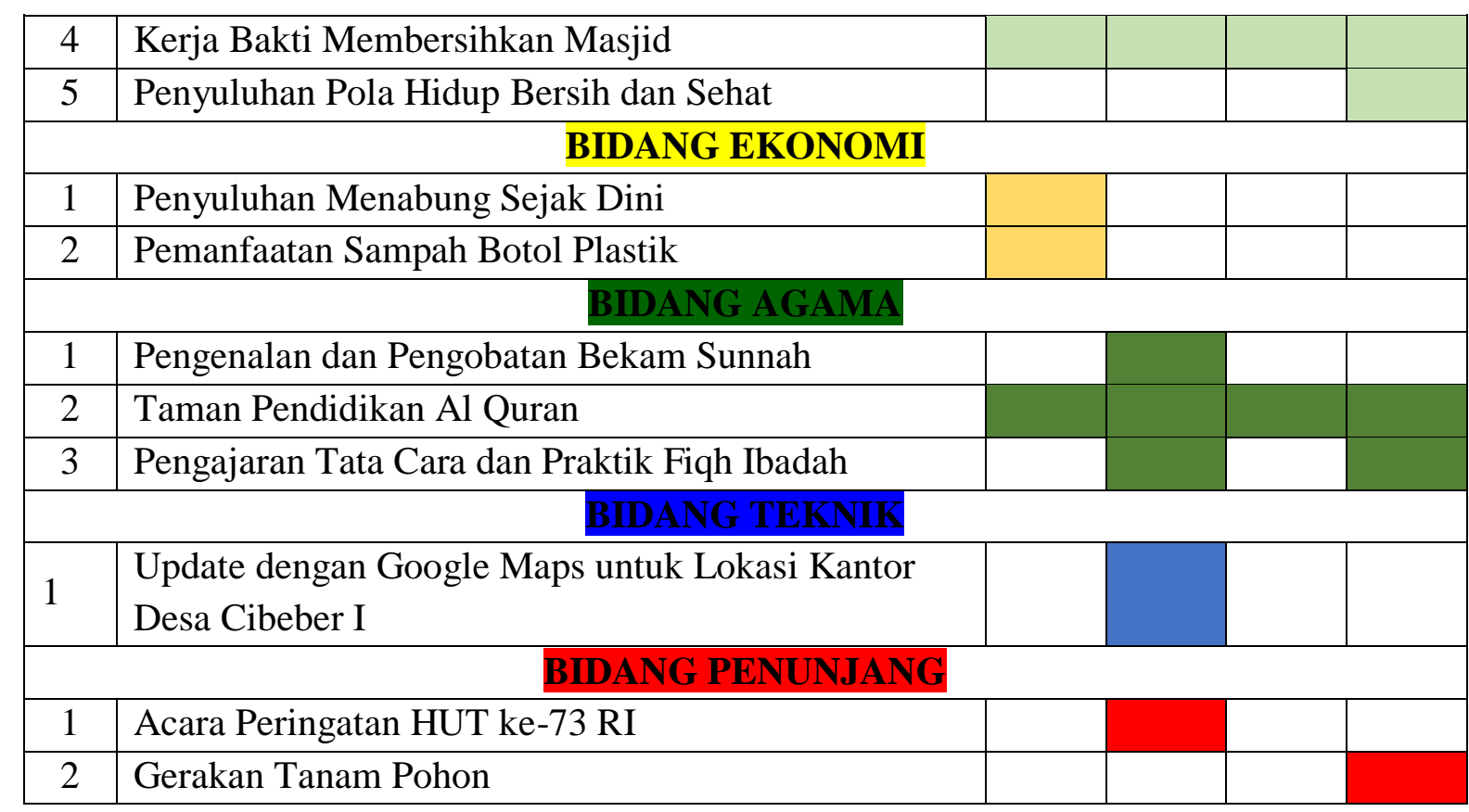

\section{Metode Pendekatan}

Dalam pelaksanaan Kuliah Kerja Nyata Tematik Terintegrasi Universitas Ibn Khaldun Tahun 2018, pendekatan yang digunakan dalam kegiatan ini, adalah berdasarkan metode Participatory Rural Appraisal (PRA) dan pendekatan sosial.

\section{Metode Participatory Rural Appraisal (PRA)}

Merupakan metode yang melibatkan masyarakat mulai dari tahap perencanaan, pelaksanaan, pemanfaatan dan evaluasi. Pendekatan tersebut memungkinkan masyarakat desa saling membagi, menambah dan menganalisis pengetahuan tentang kondisi lingkungannya dalam rangka membuat perencanaan dan tindakan. Dengan demikian metode PRA adalah cara yang digunakan dalam melakukan kajian untuk memahami keadaan atau kondisi desa dengan melibatkan partisipasi masyarakat, atau pengkajian atau penilaian terhadap keadaan desa secara partisipatif.
Penggunaan metode PRA bertujuan untuk hasil rancangan program yang relevan dengan harapan dan keadaan masyarakat, agar juga diharapkan kemampuan masyarakat dalam analisis keadaan mereka sendiri dan diwujudkan dengan pelaksanaan perencanaan dan realisasi dapat berkembang, sehingga dapat dibuat program dan pelaksanaannya. Dalam kegiatan PRA ini mahasiswa hanya sebagai fasilitator sekaligus motivator dan masyarakatlah sebagai pelaksananya.

\section{Langkah Evaluasi}

Evaluasi yang telah dilakukan terdiri atas evaluasi proses dan hasil.

a) Evaluasi proses, terkait dengan perencangan, pembinaan, dan proses pelaksanaan. Evaluasi proses dilakukan setiap pekan bersama tokoh-tokoh masyarakat dan keorganisasian yang berada di Desa Cibeber I.

b) Evaluasi hasil, dilaksanakan setelah kegiatan selesai setiap hari saat 
malam sebelum istirahat. Evaluasi hasil ditujukan untuk mengetahui sejauh mana program KKN terlaksana.

\section{REALISASI PROGRAM}

\section{Bidang Pendidikan}

Program ini dilaksanakan pada hari Selasa, 13 Agustus 2018 dan Kamis, 15 Agustus 2018. Berlokasi di Kampung Hegarmanah, Desa Cibeber I. Dalam pelaksanaannya, dibagi menjadi 3 tim. Dari kelas rendah yaitu kelas 1-3 $\mathrm{SD}$, dilanjutkan dengan pengajaran di kelas tinggi yaitu kelas 4-6 SD. Tujuan dari program ini adalah untuk membantu guru di sekolah dalam memberikan pelajaran, karena kurangnya tenaga pengajar, para mahasiswa dapat mengimplementasikan ilmu yang telah di dapat dalam perkuliahan. Jadi, program terlaksana dengan hasil capaian $100 \%$.

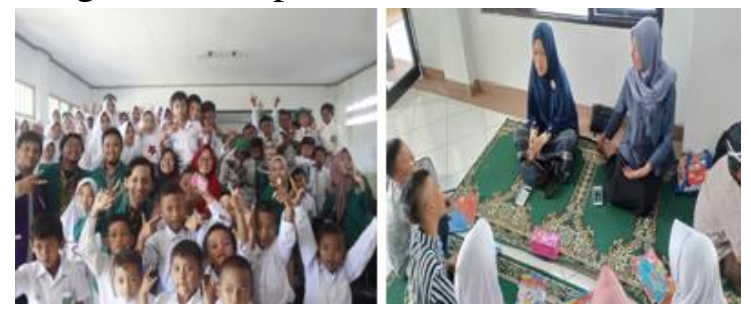

Penyelenggaraan Bimbingan Belajar

Dilaksanakan mulai hari Senin, 13 Agustus 2018 sampai Jum'at, 31 Agustus 2018. Kami mengadakan bimbingan belajar ini, agar anak-anak terbantu dalam pelajaran yang mereka anggap sulit. Hasil yang diperoleh dari bimbingan belajar ini bagi siswa yang mendapatlkan bimbel adalah siswa mendapatkan pengetahuan baru tentang cara belajar yang efektif dan mengetahui belajar yang mudah dan menyenangkan. Selain itu, setiap selesai pengajaran kami memotivasi para siswa.. Program bimbingan belajar ini dinyatakan berhasil dan sangat bermanfaat dengan capaian $100 \%$.

\section{Bidang Kesehatan dan Lingkungan}

Kegiatan Poskesdes dilakukan pada setiap hari kamis setiap pekannya di posyandu ROS 1, dimulai pada pukul 8 pagi. Kegiatan ini bertujuan untuk membantu tugas para kader serta tenaga kesehatan yang berperan dalam pelaksanaan poskesdes dan posyandu, baik itu dalam hal pendataan pasien dan peracikan atau pemberian obat. Juga alur kefarmasian di poskesdes tidak sesuai dengan standar mutu keselamatan pasien. Maka, kami hadir membawa perubahan untuk memperbaiki alur poskesdes. Pencapaian dari program ini adalah $80 \%$.
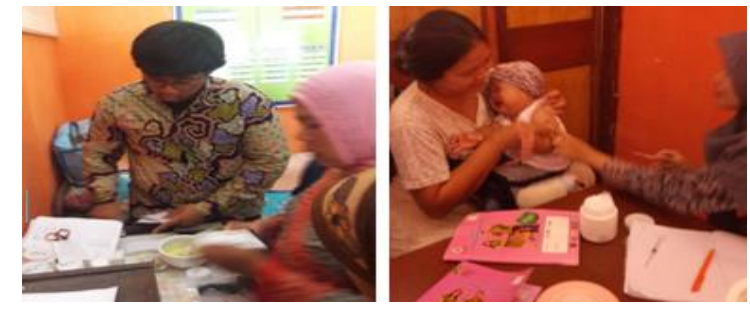

\section{Pemberian Vitamin A dan Imunisasi}

Dilaksanakan pada hari Kamis, 23 Agustus 2018. Selain pemberian vitamin A dan imunisasi campak, kami juga membagikan bubur kacang hijau untuk balita. Kegiatan ini bertujuan untuk membantu tugas para kader serta tenaga kesehatan yang berperan dalam pelaksanaan, baik itu dalam hal pendataan balita, pemberian vitamin A dan imunisasi campak. Pencapaian dari program ini adalah $80 \%$.

\section{Jalan Sehat}

Jalan sehat digelar dalam rangka memperingati HUT RI ke-73 yang dilaksanakan pada hari Minggu, 19 Agustus 2018 dan Minggu, 26 Agustus 2018. Tujuan kegiatan ini adalah mengajak masyarakat untuk hidup lebih sehat dan gemar berolahraga. Jalan Sehat ini 
mengitari sebagian Desa Cibeber I, start dari Masjid Jami Darut Taqwa dan Lapangan Bola Kampung Hegarsari. Pencapaian program ini adalah $80 \%$.

\section{Kerja Bakti Membersihkan Masjid}

Dilakukan di Masjid Jami Darut Taqwa pada hari jumat di setiap pekannya. Kegiatan ini bertujuan untuk menjaga keindahan masjid dan kenyamanan masyarakat yang beribadah ataupun melakukan kegiatan di pekarangan masjid. Adapun tujuan lain dari kegiatan tersebut adalah membangun rasa peduli masyarakat akan kebersihan lingkungan . Pencapaian dari program ini adalah $80 \%$.
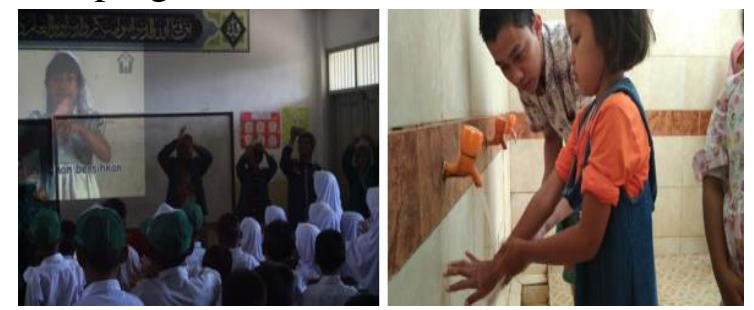

\section{Pola Hidup Bersih dan Sehat}

Kegiatan penyuluhan ini dilakukan di MI, yang melibatkan murid kelas 1-6. Kegiatan ini bertujuan untuk memberikan ilmu dan pengertian akan pentingnya menjaga perilaku hidup bersih dan sehat, serta tata cara atau langkah-langkah mencuci tangan yang benar. Dengan cara memberikan penyuluhan dalam bentuk presentasi visual, dan penjelasan secara lisan atau interaksi langsung. Pencapaian dari program ini adalah $90 \%$.

\section{Bidang Ekonomi}

\section{Penyuluhan Menabung Sejak Dini}

Kegiatan ini dilaksanakan hari Kamis, 15 Agustus 2018 bertempat di MI, yang melibatkan siswa-siswa kelas 4-6. Adapun hasil yang ingin dicapai dari kegiatan ini adalah anak - anak yang termotivasi untuk menabung dan mengerti akan pentingnya menabung untuk masa depan. Capaian dari kegiatan ini sebesar $100 \%$.

\section{Pemanfaatan Sampah Botol Plastik \\ bersama dengan kegiatan} penyuluhan menabung sejak dini. Kegiatan ini dalam bentuk pembuat kerajinan celengan, dimana bahan utama dalam pembuatannya hanya perlu botol bekas. Tujuan kegiatan ini untuk pengajaran pentingnya mendaur ulang barang-barang di sekitar dan pengajaran kreativitas, inovasi, dan pola pikir terbuka, bahwa barang yang tampak seperti sampah, tetapi masih memiliki kegunaan lebih. Pencapaian program ini sebesar $100 \%$.

\section{Bidang Agama}

\section{Pengenalan dan Pengobatan Bekam Sunnah}

Kegiatan ini dilaksanakan pada hari Sabtu, 18 Agustus 2018 bertempat di Masjid Jami Darut Taqwa untuk lakilaki dan Klinik Bidan Nyonya Peni untuk perempuan. Tujuannya untuk mengenalkan pengobatan sunnah sesuai syariat kepada masyarakat dan memanaskan aliran energi dalam darah sehingga akan menghilangkan hawa dingin, kelembapan, dan racun yang disebapkan penumpukkan obat kimiawi. Pencapaian program ini $100 \%$.

\section{Taman Pendidikan Al-Quran}

Program ini mulai dilaksanakan pada hari Jum'at, 10 Agustus 2018setelah ba'da maghrib, bertempat di rumah Bapak Yahya selaku DKM Masjid Darut Taqwa. Program untuk membantu istri Bapak Yahya yang seorang diri mengajarkan 30 anak. Dalam Program ini kami mengajarkan beberapa pelajaran diantaranya yaitu, cara membaca Al Quran yang tartil dan menghafal 99 asmaul husna. Program ini bertujuan agar anak- 
anak TPA dapat membaca Al Quran dengan baik sesuai kaidah tajwid. Dan mengenai menghafal asmaul husna kami mengajarkan cara menghafal yang menyenangkan, yaitu dengan nada yang indah ketika menghafalnya. Capaian dari program ini adalah $85 \%$.

\section{Pengajaran Tata Cara dan Praktik Fiqh Ibadah}

Fiqh ibadah yang kami ajarkan adalah fiqh wudhu dan sholat. Adapun Fiqh wudhu dilaksanakan hari Selasa, 14 Agustus 2018, sedangkan fiqh sholat dilaksanakan hari Sabtu, 01 September 2018 bertempat di Masjid Darut Taqwa. Program ini bertujuan agar masyarakat atau khususnya anak-anak tingkat SD dan SMP Kampung Hegarmanah paham betul bagaimana praktik wudhu dan sholat yang benar. Kami menyampaikan teori lalu anak-anak melakukan praktek wudhu dan sholat dengan pengawasan kami. Agar mereka tidak lupa dengan yang sudah diajarkan, kami menempel poster tata cara wudhu dan sholat di dinding Masjid. Pencapaian dari program ini sebesar $95 \%$.

\section{Bidang Teknik}

Update dengan Google Maps untuk lokasi Kantor Desa Cibeber I

Kegiatan ini dilaksanakan hari Senin, 13 Agustus 2018. Program ini dilakukan karena ketika kami melakukan observasi/survey, lokasi menuju Kantor Desa Cibeber I tidak terdeteksi di Google Maps. Pengajuan titik lokasi pada pihak Google dengan harapan warga pendatang atau wisatawan dapat dengan mudah mengetahui Kantor Desa Cibeber I. Capaian dari program ini sebesar $100 \%$.

\section{Program Penunjang}

\section{Acara Peringatan HUT ke-73 RI}

Acara ini dilakukan untuk memperingati Hari Ulang Tahun ke-73 Republik Indonesia dan untuk menumbuhkan rasa kebersamaan, solidaritas, dan semangat patrotisme dan nasionalisme. Selain itu, kami mengadakan santunan anak yatim sebagai wujud kepedulian sesame di hari besar Indonesia. Kegiatan ini menimbulkan rasa kedekatan antar masyarakat Desa Cibeber I dengan mahasiswa KKN-TT Kelompok 52.

\section{Gerakan Tanam Pohon}

Kegiatan ini bekerja sama dengan BPDAS Citarum-Ciliwung. Dilaksanakan pada hari Selasa, 04 September 2018 di Lapangan Bola Kampung Hegarsari. Kegiatan penghijauan ini melibatkan Kepala Desa serta jajarannya, Seluruh Ketua RW dan RT Desa Cibeber I, dan Karang Taruna Kujang Desa Cibeber I. Tujuan penanaman 500 pohon sebagai salah satu upaya konservasi lahan dan mitigasi bencana di Desa Cibeber I. Pasalnya masih terdapat beberapa wilayah di desa yang rawan terhadapa bencana erosi. Kegiatan ini terlaksana dengan persentase $100 \%$.

\section{KESIMPULAN}

Desa Cibeber I merupakn salah satu desa di Kecamatan Leuwiliang Kabupaten Bogor. Desa Cibeber I mempunyai banyak sekali peluang terutama dalam hal pertanian, perkebunan dan wirausaha bata merah. Hamparan persawahan yang luas dan berundak-undak menciptakan pemandangan yang begitu indah dan 
udara yang sejuk membuat Desa Cibeber I memiliki pemandangan alam yang begitu luar biasa. Ditengah potensi alam yang luar biasa ini, kenyataannya Desa Cibeber I belum dapat termanfaatkan secara maksinal. Hal ini disebabkan karena Sumberdaya Manusia yang belum berkualitas, infrastuktur kurang, dan teknologi informasi yang masih belum berkembang. Dalam kaitannya dengan Sumberdya Manusia, bidang pendidikan merupakan faktor utama penyebab kurangnya Sumberdaya Manusia berkualitas. Sebanyak apapun potensi yang ada dalam sebuah lingkungan tidak akan mampu berkembang tanpa Sumberdaya Manusia yang berkualitas. Infrastruktur dan teknologi informasi juga penting dalam pengembangan desa dalam upaya pemberdayaan ekonomi untuk peningkatan taraf hidup masyarakat.

Di Desa Cibeber I banyak sekali fasilitas penunjang yang kurang seperti fasilitas kesehatan, pendidikan, teknologi informasi bahkan akses jalanpun sungguh sangat memprihatinkan. Tingkat pendidikan yang rendah pula mempersempit peluang yang sebenarnya sangat cukup tinggi. Perekonomian masyarakat tidak dapat berkembang dengan maksimal apabila Sumber Daya Manusianya tidak berkembang pula. Dan Sumber Daya Manusia tidak dapat berkembang apabila tidak terdapat fasilitas yang memadai untuk mengebangkan bakat dan kemampuannya.

\section{SARAN}

Untuk pemberdayaan perekonomian di Desa Cibeber I dalam upaya peningkatan taraf hidup masyarakat, kelompok merekomendasikan upaya-upaya yang perlu dilakukakan Pemerintah, khususnya Pemerintah Daerah yang dalam hal ini secara langsung bertanggung jawab akan daerah kuasanya, yaitu:

1) Dalam hal pendidikan maupun kesehatan, pemerintah harus menambah dan melengkapi sarana dan prasarana menjadi lebih baik. Karena untuk meningkatkan tingkat pendidikan dan kesehatan takkan bisa dilakukan hanya dengan memotivasi masyarakat untuk menempuh pendidikan atau mensosialisasikan arti penting pendidikan dan kesehatan. Namun diperlukan fasilitas terlebih dahulu agar masyarakat dapat melaksanakan apa yang mereka butuhkan berkaitan dengan pendidikan dan kesehatan.

2) Memperbaiki akses jalan, karena akses jalan Desa Cibeber I mengalami kerusakan, sehingga masyarakat harus mengendarai kendaraan dengan lambat agar terjaga keselamatannya. Kerusakan tersebut menimbulkan kubangan air jika turun hujan.

3) Membuat Tempat Pembuangan Sampah, Desa Cibeber I merupakan desa yang masih asri. Akan tetapi keindahan desa dirusak oleh sampah yang menumpuk di sekitar sungai.. Kami telah mencoba mensosialisasikan hal ini kepada masyarakat, akan tetapi respon yang 
didapat tidak baik. Ini kewajiban Pemerintah untuk melengkapi fasilitas TPS dan memberikan ultimatum kepada masyarakat agar membuang sampah di tempat yang telah disediakan.

4) Dalam hubungannya dengan peserta KKN, Pemerintah dapat menyempurnakan program mahasiswa KKN yang belum sesuai dan melanjutkan program yang belum dapat terlaksanakan dengan baik. Hendaknya pemerintah dan lembaga perguruan tinggi dapat bekerja sama dalam menyusun kegiatan KKN, agar kegiatan yang dilakukan dapat lebih sesuai dengan keadaan dan potensi daerah demi keterwujudan masyarakat yang mandiri dan sejahtera.

\section{REFERENSI}

Desa Cibeber I. 2014. Gambaran Umum

Profil Desa Cibeber I. [Online]

diakses pada Kamis, 13

September 2018

desacibebersatu.blogspot.com/201

4/03/gambaran-umum-profil-desa-

cibeber-i_6623.html?m=1

Desa Cibeber I. 2014. Peta Desa

Cibeber I Kecamatan Leuwiliang. [Online] diakses pada Kamis, 13

September 2018 desacibebersatu.blogspot.com/201 4/03/peta-desa-cibeber-ikecamatan-leuwiliang.html?m=1

LPPM. 2018. Format Pedoman Pelaporan PPM UIKA. Universitas Ibn Khaldun Bogor. 